\title{
Education for Reform: New Students, New Methods, New Assessments
}

\author{
Jim Barrett*
}

\section{Introduction}

The last few decades have seen many new features introduced into the world of warfare, with an evident impact on those who go into harm's way on our behalf. In this article, I propose to briefly examine four developments that have brought new requirements for military education, and then to think further about what these new requirements mean for military educators. The essay will conclude with a real-life example, by sketching how this wave of change translates into military education reform in the Republic of Armenia.

The four "new" elements selected for consideration here are:

1. A new world of conflict and warfare, for which we must educate our students

2. A new world of education, featuring lifelong learning, e-learning, and learnercentered education

3. New networks of learning, including such examples as the European Higher Education Area, NATO's Defense Institution Building initiative, and the Partnership for Peace Consortium

4. Military education reform in emerging democracies, encompassing new institutions, new curricula, and new attitudes.

This list is far from complete, and the discussion offered in a brief format such as this can only be superficial at best, but they provide intriguing indicators of how military education - that fascinating bazaar where the military world and the educational world intersect - is addressing the challenges of a military education curriculum that continues to expand and that has embraced some unexpected domains. Who would have predicted fifty years ago that diversity and gender would become features of professional military education? Such topics find themselves in the curriculum in part because they reflect modern human rights sensitivities and in part because they have operational utility.

\section{Continuing Change in a Persistent Culture}

The profession of arms may be in some ways one of the most stable and enduring professions on the face of the earth. Military culture and military traditions are shared across national boundaries and across generations. But the business of the profession of arms is highly fluid, and constantly changing. While military traditions and values per-

\footnotetext{
Jim Barrett is a professor emeritus at the Royal Military College of Canada. This paper represents a compilation of the opening addresses at two Educators' Workshops held in Yerevan, Armenia from 12-14 June 2012. The four "new"s were chosen to align with the Workshop's themes.
} 
sist, each new mission brings new doctrines, new tactics, new lessons, and new thinking. The daily reports of suicide bombers, pilotless drone attacks, and cyber warfare viruses all remind us of the new complexity of the old business of warfare. Less visible than combat operations, the work of generating, managing, and sustaining armed forces has become more complicated as well. Governments demand greater financial accountability. Weapons acquisition, logistics, and financial oversight all demand modern business skills. Whole-of-government initiatives and the comprehensive approach are a growing part of the operational fabric, calling for a whole new set of knowledge and skills.

The business of assembling and sustaining a modern and sophisticated armed force falls to a large extent on the military trainer and the military educator, which means that trainers and educators have a responsibility to understand the impact of new developments in the world of defense on military teaching. This involves more than selecting the most important new concepts and absorbing them into the military curriculum. The very nature of the curriculum is changing, as many of the new demands upon it require a more thorough, more systematic, and indeed a more academic approach. As a result, we find within the traditional training paradigm an increasing component of what has become known as "professional military education." "

The first question to be asked is, How do we define the modern military education curriculum? The most obvious concern is technical. Officers and soldiers will need new technical skills to operate new capabilities. A more important challenge is how to use new weapons and techniques that have both tactical and strategic applications. The most potent example is perhaps the armed pilotless drone, a weapon that can do the bidding of a company commander in the field, or respond to the direct instructions of a head of state. The question that constantly accompanies the use of drones is whether the political reaction to a drone attack is outweighed by its military utility. ${ }^{2}$ The employment of such weapons goes well beyond their technical capabilities, and extends into the political realm. To use such weapons wisely and well, soldiers will need more than training. They will need an education.

This leads us to a third concern: the increased depth or level of sophistication of instruction. This is often framed as "education" versus "training," or perhaps captured in a taxonomy of learning. ${ }^{3}$ Training and education present a continuous spectrum, with most instructional activities situated on a sliding scale between the two extremes of "pure" training and "pure" education. The formation of soldiers in today's world demands drills designed to condition reflex action under stress, and at the same time requires the abstract study of phenomena and ideas to discern broad and universal principles. Modern military professional development is an admixture of the critical analysis that education

1 See, for instance, Peter Foot, "Military Education and the Transformation of the Canadian Forces," Canadian Military Journal 7:1 (Spring 2006): 13-20.

2 Stephanie Nolen, "A Taboo Thought in Pakistan: What if Drones Work?," The Globe and Mail (Toronto) (17 November 2012).

3 See, e.g., Benjamin S. Bloom, Max D. Engelhart, Edward J. Furst, Walker H. Hill, and David R. Krathwohl, Taxonomy of Educational Objectives: The Classification of Educational Goals, Handbook I: Cognitive Domain (New York, NY: Longmans, Green, 1956). 
affords, and the instincts for effective action that training and repetition alone can deliver. The expected result of military education is critical thinking in the face of the unknown - the soldier's ability to make a reasoned response in the face of an unpredictable situation. ${ }^{4}$

Though many might argue that the future of warfare is not the business of military educators, the preparation of our national military forces to meet present and future threats is certainly the business of military educators. We have two responsibilities here. The first is to develop and deliver the curriculum that is appropriate for today's soldier. The second responsibility, less obvious but equally important, is to develop and sustain the academic engine that enables force generation, including the defense intellectuals and military thinkers - the new Clausewitzes - who will generate the theoretical frameworks for future curricula, and who will provide reasoned and balanced advice for the new commanders. Too often, it is assumed that those who are responsible for training and education can be either assigned, or perhaps hired, at will. This is less true today than ever. The military training and education establishment needs to be grown, and nurtured, as perhaps the most essential element of the force generation framework.

\section{New Tools for a New World of Military Education}

The foot soldiers of that academic engine-instructors and professors, subject matter experts, curriculum developers - wrestle not only with the changing military world but also struggle with new challenges that arise from within the world of education itself. Schools and universities, private enterprise, and governments have all felt the shock wave of two powerful trends.

The first, glaringly obvious shift is the growth of the Internet and social media. The impact of that revolution is all around us. The response of the educational community can be seen in the explosion in the number of courses offered via the Internet, or through mobile platforms such as the iPhone. Military education too has responded vigorously. In spite of resistance from traditional residential programs, online military education today has the capability to educate and instruct large cohorts of soldiers in a short period of time. An early example is the "Introduction to NATO" online course pioneered by the NATO Defense College. ${ }^{5}$ This short course was designed and assembled by a multi-national team in less than a year, and it remains available to military personnel and interested persons around the world, in effect to a classroom without limits. The essential ingredients - as has always been the case-are competent instructors or subject matter experts, backed up by professional instructional design and a supported learning manage-

4 Ronald G. Haycock, "Clio and Mars in Canada: The Need for Military Education," presentation to the Canadian Club, Kingston, Ontario (11 November 1999).

5 For further details, see the NATO Defense College website, at www.ndc.nato.int/education/ courses.php?icode $=15$. 
ment system (LMS). ${ }^{6}$ Online learning and e-learning have made the once impossible merely expensive, and as we continue to learn from our experience, the once expensive forms of education will become affordable, and even routine.

The second powerful trend is a tremendous increase in demand for what we have come to call lifelong learning. Driven by rapid advances in technology, an increased emphasis on a systems approach in business, and on the growing popularity of learningbased after-action analysis, working adults of all ages seek access to education to stay current in their jobs, to acquire new knowledge for advancement, or just to understand the world around them. In the old days, school was a "fire and forget" concept, a place where the young were sent to prepare for a lifetime of work. Seldom, if ever, would graduates return to school. Today, working adults often return to school to stay abreast of modern ideas, modern techniques and modern tools. The military reflection of this larger trend can be seen in what we call "professional military education" (PME). Perhaps not surprisingly, PME often proves to be a challenge to our conventional and conservative thinking. Instruction on a massive scale challenges ideas rooted in the environment of the residential schoolhouse, and the increased access to learning for the junior ranks challenges conventional military hierarchies. However, both these features represent real opportunity.

Together, these two trends are changing the face of education. This change constitutes a much larger shift than simply delivering courses via the Internet. More interesting are the often startling experiments in e-learning that draw on online forums and communities, testing new course structures and new learning philosophies. Perhaps the most dramatic innovation is the massive open online course (MOOC), ${ }^{7}$ which is an online course offering provided by consortia of highly respected universities to thousands of students at once. ${ }^{8}$ The courses are offered without cost, all reference material is available online, and grading is done by peers. ${ }^{9}$ There are serious problems still to resolve, but the universities that have pursued this path are serious about working these out. The MOOC is only one of many educational experiments, but there is little doubt that the schoolhouse is changing radically. What will abide is the demand of adult students, including military students, for reliable and current content, quality assurance and, frequently, certification. It is not clear where all this will lead, but it is clear that those who argue that there is nothing new here, or that traditional face-to-face, in-garrison instruc-

6 See, for instance, ILIAS, the learning management system that supports online courses offered through the PfP Consortium: https://www.ilias.de/docu and www.isn.ethz.ch/e-Education/TheISN-TACC/Advanced-Distributed-Learning-Working-Group.

7 For more insight into the MOOCs, see www.youtube.com/watch? $\mathrm{v}=\mathrm{eW} 3 \mathrm{gMGqcZQc}$ and www.nytimes.com/2012/11/04/education/edlife/massive-open-online-courses-are-multiplyingat-a-rapid-pace.html?pagewanted=all\&_r=0.

8 For example, one consortium, Coursera, engages thirty-three universities, including Columbia, the University of California, Princeton, Stanford, the University of Toronto, the University of London, l'École Polytechnique Fédérale de Lausanne, and the University of Melbourne.

9

Courses are offered free of charge, unless academic credit is sought for the course. 
tion is the only acceptable paradigm have not been paying attention. More seriously, they are missing the tremendous opportunities offered by these new approaches.

When judiciously applied to appropriate content, the new learning models free up precious residential time and facilities. As no single individual can be expected to master all of a fast-moving military curriculum, a useful approach is to define an essential core curriculum to be given face-to-face, in-garrison, supplemented by a wide range of pertinent content available to defined segments of the military population (or, if appropriate, to the entire population). For this approach to succeed, the ability to learn, to assess critically, and to filter key information must be essential features of modern military education. The learner-centered approach creates access to a tremendously expanded military curriculum, one that is readily adaptable to national and local requirements, and has moreover the ability to keep pace with change.

It is a mistake to think that what worked in the past will continue to serve us well. In the first place, the world is changing so dramatically and so quickly that residential schoolhouses with limited capacity can no longer cope. In the second place, our young recruits, who have grown up with the Internet and smartphones, will not long tolerate our antiquated way of doing business. Military education will have little choice but to adapt to the world around it, and to its digital citizens.

\section{Networks for Learning}

If we wished to describe the result of the Internet revolution in a single word, that word might well be "connectedness." We have all become linked, almost without being conscious of it, through an increasingly affordable global communications network. This connectedness is expressed too in more formal, institutional ways. In the European Higher Education Area, the Bologna Agreement has established common university standards, and similar agreements have established common standards for vocational training. ${ }^{10}$ A student can take courses - residential or online-from a number of European universities and colleges to acquire a European credential. Similar networking exists for military education. Many European staff colleges have adopted the educational standards of the Bologna process, ${ }^{11}$ while the European military Erasmus Initiative promotes the exchange of young officers, professors, and even courses among military education establishments, with the aim of developing common academic standards and, ultimately, a common defense and security structure. ${ }^{12}$

At the strategic level, the NATO Conference of Commandants meets annually to consider current issues in military education. ${ }^{13}$ This group, originally a NATO-only conference, now includes nations from the Partnership for Peace (PfP),${ }^{14}$ the Mediterranean

10 See www.ehea.info and http://ec.europa.eu/education/lifelong-learning-policy/ecvet_en.htm.

11 Poland and Romania are two good examples of this.

12 See, fore example, www.emilyo.eu/.

13 See www.ndc.nato.int/news/current_news.php?icode=285.

14 Background is available at www.nato.int/cps/en/natolive/topics_50349.htm. 
Dialogue,${ }^{15}$ and the Istanbul Cooperation Initiative. ${ }^{16}$ At a less rarefied working level we find the activities of the NATO/PfP Partnership Action Plan in Defense Institution Building (PAP-DIB), which aims to assist Partner countries in the reform of their defense institutions, including the institutions of military education. ${ }^{17}$

The PAP-DIB initiative is led and sustained by two agencies that cooperate closely. The Political Affairs and Security Policy Division of the NATO International Staff draws on an ad hoc network of contributors who offer their services through "clearing houses," which are meetings convened to match Partner needs with donor expertise. The Partnership for Peace Consortium of Defense Academies and Security Studies Institutes (PfP Consortium) is a more formal network of some 300 institutions that contribute members to the Consortium's six Working Groups, as well as to NATO's informal network. ${ }^{18}$ The Education Development Working Group is a major contributor to the PAPDIB project. ${ }^{19}$

There are three main PAP-DIB activities that support military education reform. The first is the development of a series of Reference Curricula. Current activity in this area is aimed at the development of a Reference Curriculum for NCO professional military education. ${ }^{20}$ The second element is an Educators' Program for Partners' instructional staff, designed to expose new approaches to course design, teaching, and learning, including the application of the latest learning methods. The third element is the Defense Education Enhancement Program, or DEEP, a series of in-country visits by multinational teams providing expert advice and support as Partner nations seek to implement defense education reforms as laid out in an Individual Partner Action Plan (IPAP) or a Membership Action Plan (MAP). At the time of writing, there are ten countries with routine or planned visits from DEEP teams.

These three activities truly represent a rich network of supporting nations, institutions, and individuals that provide Partners with exposure to modern concepts and best practices. Change management can start with guidance from the top, but at every level of execution leaders and managers will interpret and filter that guidance to shape their response. Exposure to recent developments in military education helps to develop a cadre of military leaders and managers who understand the intent and purpose of change, and who have an enthusiasm for what those changes will bring. The last element is the network itself and the network model - building links among military educational institutions, building links to civilian institutions, and extending and sustaining the network. This is a network with connections that transcend any current task, and that will persist long after that task is done. For the PfP Consortium, two key challenges will persist: the

15 For further details, see www.nato.int/cps/en/natolive/topics_52927.htm.

16 See www.nato.int/cps/en/natolive/topics 52956.htm.

17 More information on the PAP-DIB initiative is available at www.nato.int/cps/en/natolive/ topics_50083.htm.

18 See the PfP Consortium Website, at https://pfpconsortium.org/node/5/about.

19 See the paper by John Berry in this issue.

20 "NATO Launches Reference Curriculum for Defense Institution Building," available at www.nato.int/cps/en/natolive/news_57397.htm. 
first is to coordinate and fund the work of its Working Groups, and the second is finding ways to sustain the multinational character of its extraordinary network of nations, institutions, and individuals.

\section{Armenia's Challenge}

The first DEEP visit to the Republic of Armenia was in May 2008. The visitors found a small landlocked country pinched at the intersection of three old empires, with its eastern and western borders closed to trade and a simmering "frozen" conflict with its neighbor, Azerbaijan. ${ }^{21}$ While seeking closer ties with Europe and the West, Armenia remains an ally of Russia and will not seek NATO membership. The Armenian population of approximately 3.5 million is well educated, with a literacy rate close to 100 percent.

The Armenian armed forces are, for the most part, designed on the old Soviet model, organized around regiments of motorized rifle companies. ${ }^{22}$ There is a professional officer corps, but no professional NCO corps, and the majority of soldiers are conscripts. Military reform in Armenia is driven by a desire to build a modern force appropriate to Armenia's circumstances and strategic situation, "a new army for a new Armenia." But for this new nation, reform is not a trivial challenge. The frozen Nagorno-Karabakh conflict creates constant pressure to concentrate on the immediate imperatives of self-defense. Even so, this young republic also looks to the long term and the broader spectrum of its defense and security needs.

Apart from the creation of a NATO-interoperable Peacekeeping Brigade, defense reform in Armenia has progressed slowly. In part this is because the military education institutions that would ordinarily generate new thinking and underpin a reform agenda do not exist in Armenia. Armenia began life as a new republic with no military education facilities whatever. The military academies, staff colleges, and war colleges that are the pivotal institutions of a developed military education system were all located elsewhere in the Soviet Union. ${ }^{23}$ The establishment in 1993 of a military institute named after V. Sargsyan and the Military Aviation Institute was a vital achievement, but in 2012 there is still little education capacity for Armenian officers at mid-career and beyond. For the Republic of Armenia, this means that the creation of its new command and staff course, and then the establishment of a new command and staff academy to house the course, is a matter of the highest importance.

The first task of the visiting DEEP experts was to advise on the creation of a Defense Education Concept, which confirmed the need to build a command and staff course. The resulting project has become a central focus for the DEEP visitors. The new curriculum, representing a fundamental shift from a restricted command doctrine to one that more closely resembles Western mission command, will mean a radical departure from the

\footnotetext{
21 For a strategic overview of Armenia's situation, see the CIA World Factbook entry, available at https://www.cia.gov/library/publications/the-world-factbook/geos/am.html.

22 Each regiment roughly the equivalent of three battalions.

23 See the article by Hajk Kotanjian in this issue.
} 
Soviet model for the Armenian armed forces. Moreover, the new program will be developed to the standards required by the Bologna process under the combined authority of the Minister of Defense and the Minister of Education. This critical project is on track to launch a pilot course in 2013, with the first substantive command and staff course to be given in 2014.

The launch of a modern course for senior officers is only the beginning. It will bring reform, but will also put considerable stress on a conservative military. Other reform projects - most notably the creation of a professional NCO corps - can be expected to have an equally dramatic impact. Westerners sometimes fail to grasp how difficult these changes can be. One Armenian colonel tells us that every officer who was born during Soviet times has something of a split personality. One personality remains loyal to the army where he began his service and developed his military traditions. The other personality has been to Western Europe, and to the United States, and has come to understand that the army he serves is not yet a modern army. So he is two people-a Soviet officer and a modern officer-and every day these two personae wrestle with each other to find an Armenian solution.

The DEEP project in Armenia succeeds, then, as an extended conversation with trusted colleagues - representatives of the Ministry of Defense and the Military Institute-asking and answering questions to reveal the philosophies and concepts underlying modern Western military practice. Narrowly focused support projects and events provide substance to that sustained conversation. Armenia is learning especially from new NATO nations, who have gone down this same path a few years earlier. The DEEP collaboration thus provides a wide spectrum of professional and national experience, and offers useful opportunities for faculty shadowing, expert visits, workshops, and invitations to visit the defense education facilities of other nations. For the Republic of Armenia, this is an exceptionally valuable resource as it builds its military education system, neither for the present nor the past, but for tomorrow.

\section{Conclusion}

The Republic of Armenia provides a first-rate illustration of the changing world of military education. This newly independent state maintains a careful balance between East and West, maintaining good relations and its military alliance with the Russian Federation at the same time as it seeks to enrich its relations with Europe and NATO. Western models must be adapted with some sensitivity to the Armenian situation. In the end, Armenia will select what it needs from the array of Western options that it views, deciding on what it deems best for the future of the Republic. In short, military education reform is, as it must be, an Armenian-directed project, with Western encouragement and support.

In the West, the great wave of enthusiasm for military education that followed the dissolution of the Soviet Union is starting to ebb. In the East, the importance of military education has not diminished to the same extent. There are reasons for this, not least the European project to increase the integration of military and civilian education, and to increasingly draw on civilian resources to educate armed forces. The other contributing 


\section{THE QUARTERLY JOURNAL}

factor is the intense introspection and analysis that newly independent states have undertaken to determine what their needs are in this new security environment, and what capacities they can afford. There is much that the "old West" can gain from assessing the new models of military education that we see emerging in Eastern Europe and Central Asia. These new systems may not yet be mature, or fully developed, but they are often conceived in interesting ways that are well adapted to local conditions. There is much we can learn from each other. 


\section{Bibliography}

Bloom, Benjamin S., Max D. Engelhart, Edward J. Furst, Walker H. Hill, and David R. Krathwohl. Taxonomy of Educational Objectives: The Classification of Educational Goals, Handbook I: Cognitive Domain. New York, NY: Longmans, Green, 1956.

Foot, Peter. "Military Education and the Transformation of the Canadian Forces." Canadian Military Journal 7, no. 1 (2006): 13-20.

Nolen, Stephanie. "A Taboo Thought in Pakistan: What if Drones Work?" The Globe and Mail (Toronto) (2012). 